\title{
Novel 4-Thiazolidinone Derivatives as Anti-Infective Agents: Synthesis, Characterization, and Antimicrobial Evaluation
}

\author{
Amit Gupta, Rajendra Singh, Pankaj K. Sonar, and Shailendra K. Saraf \\ Faculty of Pharmacy, Babu Banarasi Das Northern India Institute of Technology, Sector-II, Dr. Akhilesh Das Nagar, \\ Faizabad Road, Lucknow, Uttar Pradesh 227105, India \\ Correspondence should be addressed to Shailendra K. Saraf; dirpharmniec@gmail.com
}

Received 30 November 2015; Revised 7 January 2016; Accepted 12 January 2016

Academic Editor: Paul W. Huber

Copyright (C) 2016 Amit Gupta et al. This is an open access article distributed under the Creative Commons Attribution License, which permits unrestricted use, distribution, and reproduction in any medium, provided the original work is properly cited.

A series of new 4-thiazolidinone derivatives was synthesized, characterized by spectral techniques, and screened for antimicrobial activity. All the compounds were evaluated against five Gram-positive bacteria, two Gram-negative bacteria, and two fungi, at concentrations of 50,100, 200, 400, 800, and $1600 \mu \mathrm{g} / \mathrm{mL}$, respectively. Minimum inhibitory concentrations of all the compounds were also determined and were found to be in the range of $100-400 \mu \mathrm{g} / \mathrm{mL}$. All the compounds showed moderate-to-good antimicrobial activity. Compounds 4a [2-(4-fluoro-phenyl)-3-(4-methyl-5,6,7,8-tetrahydro-quinazolin-2-yl)-thiazolidin-4-one] and 4e [3-(4,6-dimethyl-pyrimidin-2-yl)-2-(2-methoxy-phenyl)-thiazolidin-4-one] were the most potent compounds of the series, exhibiting marked antimicrobial activity against Pseudomonas fluorescens, Staphylococcus aureus, and the fungal strains. Thus, on the basis of results obtained, it may be concluded that synthesized compounds exhibit a broad spectrum of antimicrobial activity.

\section{Introduction}

Infections caused by microbes are among the leading causes of death worldwide. The availability of limited number of antibiotics for the treatment of infections, and continuous development of resistance to the recently used antimicrobial agents, pose a serious challenge [1]. Thus, the discovery of innovative and potent antimicrobial agents may be the only way to resolve the resistance problem and develop successful remedy for the treatment of infectious diseases. 4-Thiazolidinones have recently been reported to be novel inhibitors of the bacterial enzyme Mur B (a precursor during the biosynthesis of peptidoglycan) and also to block some pathogenic mechanisms of bacteria [2]. 4-Thiazolidinones are derivatives of thiazolidine with a carbonyl group at the fourth position. This is a core structure in various synthetic pharmaceuticals displaying a broad spectrum of biological activities such as antimycobacterial [3-5], antimicrobial [6-19], anticancer [20,21], anticonvulsant [22-32], anti-inflammatory and analgesic [33-37], antiparasitic [3843], antiviral and anti-HIV [44-49], antidiabetic [50-52], antihypertensive [53-55], antihyperlipidemic [56-58], and MAO inhibitors [59]. The substituted thiazolidine moiety has attracted considerable interest in the development of biologically active compounds. In the present study, novel arylidene substituted 4 -thiazolidinones were synthesized and evaluated as antimicrobial agents from heterocyclic scaffold.

\section{Materials and Methods}

All the chemicals and solvents used in the study were procured from S. D. Fine-Chem. Ltd., Mumbai, and SigmaAldrich Chemie, Germany. Culture media for antimicrobial screening were procured from HiMedia Laboratories, Mumbai. The standard microbial strains were procured from Microbial Type Culture Collection (MTCC), Institute of Microbial Technology, Chandigarh, India. Spectral studies (IR, NMR, and mass spectrometry, Table 1) of the synthesized compounds were performed at Central Drug Research Institute, Lucknow.

2.1. Chemistry. 4-Thiazolidinones were synthesized in two steps. In the first step, 2-aminopyrimidine derivatives were synthesized by the reaction of 1,3-dicarbonyl compounds with guanidine. Final compounds $(\mathbf{4 a}-4 \mathbf{f})$ were synthesized 
TABLE 1: Physical and spectral characterization of the synthesized compounds (4a-4f).

\begin{tabular}{|c|c|c|c|c|c|}
\hline Comp. & Melting range & $\%$ yield $(w / w)$ & $\mathrm{IR}(\mathrm{KBr}) \mathrm{cm}^{-1}$ & $\begin{array}{r}\text { Mass } m / z \\
{[\mathrm{M}+1]^{+1}}\end{array}$ & $\begin{array}{l}{ }^{1} \mathrm{H} \text { NMR } \\
(\delta \mathrm{ppm})\end{array}$ \\
\hline $4 a$ & Viscous liquid & 32.15 & $1728.1,3453.60,1217.2$ & 345 & $2.37,3.47,7.60-6.46$ \\
\hline $4 b$ & Viscous liquid & 59.89 & $1637.4,3445.9,1216.40$ & 374 & $\begin{array}{c}2.04-2.74,3.18-3.95 \\
7.5-6.4\end{array}$ \\
\hline $4 c$ & $128-130^{\circ} \mathrm{C}$ & 40.11 & $\begin{array}{c}1711.4,3418.6,1216.4 \\
763.7 \\
\end{array}$ & 356 & $\begin{array}{c}2.73,3.32,3.93,4.35 \\
7.85-6.88 \\
\end{array}$ \\
\hline $4 d$ & $178-180^{\circ} \mathrm{C}$ & 43.04 & $1691.9,3296.7,1592.6$ & 340 & $\begin{array}{c}1.89,2.50,3.07,4.28 \\
7.87-6.87\end{array}$ \\
\hline $4 e$ & $114-116^{\circ} \mathrm{C}$ & 59.80 & $\begin{array}{c}1584.2,3427.9,1216.4 \\
1707.4\end{array}$ & 316 & $\begin{array}{c}1.25,3.67,3.33,4.29 \\
7.85-6.56\end{array}$ \\
\hline $4 f$ & Viscous liquid & 37.48 & $1663.20,3021.20,1217.00$ & 306 & $\begin{array}{c}1.91,2.56,3.33,5.09 \\
6.92-6.80\end{array}$ \\
\hline
\end{tabular}

by the reaction of compounds of step 1 with substituted aromatic aldehyde (s) and mercaptoacetic acid (s), using DCC as intramolecular cyclizing agent (Figure 1).

2.1.1. General Procedure for the Synthesis of Compounds $(3 a-3 c)$. Equimolar solution of dicarbonyl compounds and guanidine in ethanol was refluxed at $78^{\circ} \mathrm{C}$ for $8 \mathrm{hr}$. The reaction mixture was then concentrated to dryness under reduced pressure and the residue was partitioned in ethyl acetate. The organic layer was successively washed with water and then finally with brine. The organic layer was dried over sodium sulphate and the solvent was removed under reduced pressure to get the products $(\mathbf{3 a}-\mathbf{3 c})$ [49]. The progress of the reaction was monitored by TLC, using $5 \%$ methanol in chloroform.

2.1.2. General Procedure for the Synthesis of Compounds (4a4f). A solution of $\mathbf{3 a}-\mathbf{3 c}(10 \mathrm{mmol})$ and various substituted aldehydes (20 mmol) was stirred in THF, under ice cold conditions for $5 \mathrm{~min}$, followed by the addition of mercaptoacetic acid $(30 \mathrm{mmol})$. After $5 \mathrm{~min}$, DCC $(12 \mathrm{mmol})$ was added to the reaction mixture at $0^{\circ} \mathrm{C}$ and the reaction mixture stirred for an additional $5 \mathrm{hr}$ at room temp. DCU was removed by filtration, the filtrate was concentrated to dryness under reduced pressure, and the residue was extracted with ethyl acetate. The organic layer was successively washed with 5\% aqueous citric acid, water, and 5\% aqueous sodium hydrogen carbonate and then finally with brine. The organic layer was dried over sodium sulphate and the solvent was removed under reduced pressure to get the products $(\mathbf{4 a - 4 f})$ [60]. The progress of the reaction was monitored by TLC, using the solvent system methanol: chloroform $(2: 98)$.

\subsection{Antimicrobial Screening}

2.2.1. Test Microorganisms. Antimicrobial activity of the synthesized compounds was studied against nine microorganisms, including seven bacterial strains-Bacillus subtilis (MTCC 441), Staphylococcus aureus (MTCC 1430), Pseudomonas aeruginosa (MTCC 424), Bacillus pumilus (MTCC 1456), Pseudomonas fluorescens (MTCC 2421), Escherichia coli (MTCC 1573), and Micrococcus luteus (MTCC 1538)and two fungal strains, Aspergillus niger (MTCC 2546) and Penicillium chrysogenum (MTCC 161).

2.2.2. Preparation of the Samples and Standard Solution. The compounds (4a-4f) were dissolved in 10\% DMSO at the concentrations of $50,100,200,400,800$, and $1600 \mu \mathrm{g} / \mathrm{mL}$, respectively. Norfloxacin and fluconazole, used as the standard drugs for antibacterial and antifungal studies, respectively, were also dissolved in 10\% DMSO at the concentrations of $10 \mu \mathrm{g} / \mathrm{mL}$.

2.2.3. Method. Antimicrobial activity of the synthesized compounds was evaluated by cup-plate method. Nutrient broth suspension of test microorganism $(10 \mathrm{~mL})$ was added to $100 \mathrm{~mL}$ of sterile molten nutrient agar growth media (cooled to $45^{\circ} \mathrm{C}$ ), mixed well, and poured on to sterile petri plates. The agar was allowed to solidify and was then punched to make six wells/cups, using a $6 \mathrm{~mm}$ sterile cork borer (separate borer for each organism), to ensure proper distribution of wells in the periphery and one well in the centre. Agar plugs were removed and $50 \mu \mathrm{L}$ solution of test samples (each compound in six concentrations) was poured into the corresponding marked well using micropipette. Triplicate plates of each organism were prepared. The plates were left at room temperature for $2 \mathrm{~h}$ to allow diffusion of samples and then incubated face upward, at corresponding temperature of each organism, for $48 \mathrm{~h}$ [61]. The diameters of zone of inhibition were measured to the nearest millimeter (the cup size also included) and are presented in Table 2.

2.2.4. Determination of Minimum Inhibitory Concentration (MIC). A series of glass tubes, containing different concentrations of the synthesized compounds (in 10\% DMSO), with nutrient broth was inoculated with the required quantity of the inoculums to obtain a suspension of microorganisms which contained $10^{5}$ colony forming units per milliliter. One growth control tube was prepared without the addition of the compounds or the microorganisms. The tubes were incubated at $37^{\circ} \mathrm{C}$ for $24 \mathrm{~h}$. The turbidity produced in each 
<smiles>Cc1cc(C)nc(N2C(=O)CSC2C2CCC2)n1</smiles>

$(4 a-4 b)$

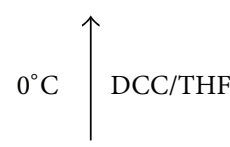<smiles>O=C(O)C[Sb]</smiles><smiles>Cc1cc([18F])nc(N)n1</smiles>
4,6-Dimethyl-pyrimidin-2-ylamine (3a)<smiles>COc1ccccc1C</smiles><smiles>Cc1ccc(C)s1</smiles>

$78^{\circ} \mathrm{C}$

Reflux $8 \mathrm{hr}$ ethanol thanol

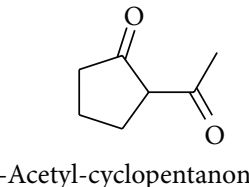<smiles>CC(=O)C1CCCCC1=O</smiles>

2-Acetyl-cyclohexanone

$78^{\circ} \mathrm{C}$

Reflux $8 \mathrm{hr}$

ethanol<smiles>Cc1nc(N2C(=O)CSC2C2CCC2)nc2c1CCCC2</smiles>

(4c-4e)

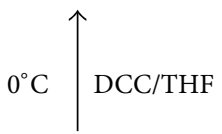

$\mathrm{HSCH}_{2} \mathrm{COOH}$

$+$

$\mathrm{Ar}-\mathrm{CHO}$<smiles>Nc1nc([18F])c2c(n1)CCCC2</smiles>

4-Methyl-5,6,7,8-tetrahydro-quinazolin-2-ylamine

(3b)

$78^{\circ} \mathrm{C}$

Reflux $8 \mathrm{hr}$ ethanol

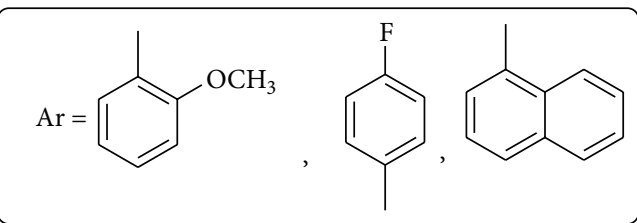

4-Methyl-6,7-dihydro-5H-cyclopentapyrimidin-2-ylamine

$(3 c)$<smiles>COc1ccccc1C=O</smiles>

2-(2-Methoxy-phenyl)-3-(4-methyl-6,7-dihydro-5H-cyclopentapyrimidin-2-yl)-thiazolidin-4-one

(4f)

FIGURE 1: Synthetic pathway for the compounds (4a-4f). 
TABLE 2: Mean diameter of zone of inhibition ( $\mathrm{mm}$ ) of synthesized compounds (4a-4f), standard and control against various microorganisms.

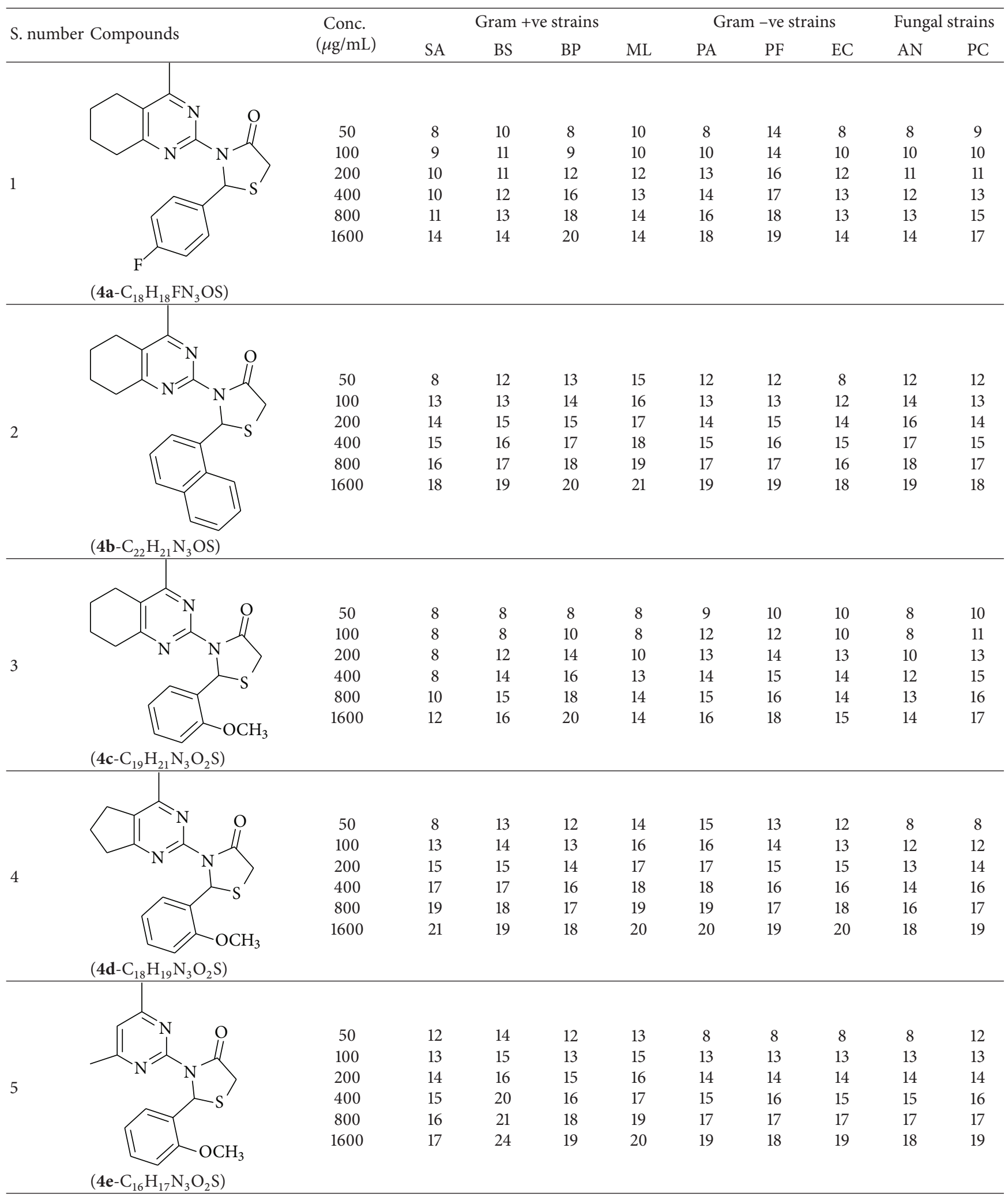


TABLE 2: Continued.

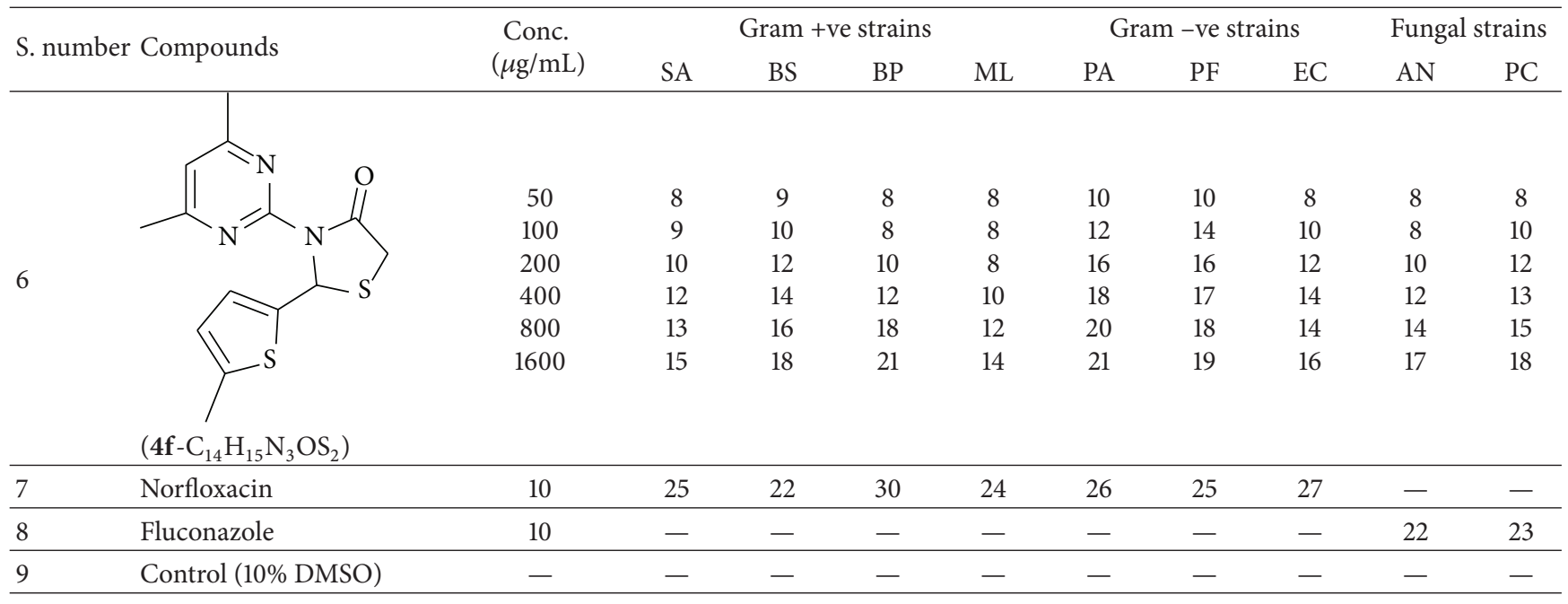

BS: B. subtilis, SA: S. aureus, BP: B. pumilus, ML: M. luteus, PA: P. aeruginosa, EC: E. coli, PF: P. fluorescens, AN: A. niger, PC: P. chrysogenum, control = 10\% v/v DMSO, and $(-)=$ no activity.

TABLE 3: Values of the minimum inhibitory concentration of the synthesized compounds and reference standards.

\begin{tabular}{|c|c|c|c|c|c|c|c|c|c|}
\hline \multirow{2}{*}{ S. number } & \multirow{2}{*}{ Microbial strains } & \multicolumn{8}{|c|}{ MIC of compounds $(\mu \mathrm{g} / \mathrm{mL})$} \\
\hline & & $4 a$ & $4 b$ & $4 c$ & 4d & $4 e$ & $4 f$ & $\mathrm{~N}$ & $\mathrm{~F}$ \\
\hline 1 & Staphylococcus aureus & 300 & 500 & 300 & 400 & 400 & 300 & 2.5 & - \\
\hline 2 & Bacillus subtilis & 300 & 200 & 400 & 300 & 300 & 100 & 5 & - \\
\hline 3 & Bacillus pumilus & 300 & 100 & 300 & 100 & 200 & 500 & 1.25 & - \\
\hline 4 & Micrococcus luteus & 300 & 500 & 500 & 300 & 300 & 300 & - & - \\
\hline 5 & Pseudomonas aeruginosa & 200 & 300 & 300 & 300 & 400 & 400 & 2.5 & - \\
\hline 6 & Pseudomonas fluorescens & 100 & 100 & 300 & 100 & 200 & 300 & 2.5 & - \\
\hline 7 & Escherichia coli & 300 & 100 & 300 & 400 & 400 & 200 & 2.5 & - \\
\hline 8 & Aspergillus niger & 300 & 100 & 100 & 100 & 300 & 300 & - & 2.5 \\
\hline 9 & Penicillium chrysogenum & 400 & 100 & 100 & 100 & 300 & 300 & - & 1.25 \\
\hline
\end{tabular}

$\mathrm{N}$ : norfloxacin and F: fluconazole.

tube was recorded on a UV-visible spectrometer $[62,63]$. The observed MICs $(\mu \mathrm{g} / \mathrm{mL})$ are presented in Table 3.

\section{Results and Discussion}

4-Thiazolidinones were synthesized in two steps. In the first step, 2-aminopyrimidine derivatives were synthesized by the reaction of 1,3-dicarbonyl compounds with guanidine. Finally, the compounds $(\mathbf{4 a}-\mathbf{4 f})$ were synthesized by reaction of the compounds of step 1 with substituted aromatic aldehydes and mercaptoacetic acids, using DCC as intramolecular cyclizing agent.

Characteristic peaks were observed for N-H stretching, $\mathrm{C}=\mathrm{O}$ stretching, and $\mathrm{C}-\mathrm{N}$ stretching. The IR spectra of the 4-thiazolidinone derivatives exhibited $\mathrm{C}=\mathrm{O}$ lactam amide stretching vibration in the range of $1637-1728 \mathrm{~cm}^{-1}$. [M] $]^{+} /[\mathrm{M}$ $+1]^{+}$peaks were observed for the synthesized compounds.

${ }^{1} \mathrm{H}-\mathrm{NMR}$ spectra of the compounds indicated the presence of two diastereotopic protons at C-5 position and one single proton at C-2 position; doublets were obtained in the region of 3.07-3.47 ppm. A doublet integrated for one proton appeared at the $\delta$ value of $2.37-2.74 \mathrm{ppm}$. This can be attributed to the $\mathrm{C}-2$ proton of the 4-thiazolidinone ring.

The antimicrobial activity was observed at 50, 100, 200, 400,800 , and $1600 \mu \mathrm{g} / \mathrm{mL}$, respectively (Table 2). Minimum inhibitory concentrations of the synthesized compounds were also determined, in nutrient broth by tube dilution method. MICs were in the range of $100-500 \mu \mathrm{g} / \mathrm{mL}$, which were recorded as the optical density, at $530 \mathrm{~nm}$.

The antimicrobial screening revealed that all the synthesized compounds possessed a wide spectrum of antimicrobial profile against the tested microbial strains. The compounds, which were active against bacterial and fungal strains, were effective at a much higher concentration than the standard drugs norfloxacin and fluconazole. All the compounds exhibited good-to-moderate antimicrobial activity against all the strains. Compounds $\mathbf{4 b}, \mathbf{4 c}$, and $\mathbf{4 d}$ were found to be more effective against the fungal strains than the bacterial strains. On the basis of MIC values of the synthesized compounds, the order of antimicrobial spectrum was $\mathbf{4 b}>\mathbf{4 a}>\mathbf{4 d}>\mathbf{4 c}$ $>$ 4f $>$ 4e. Compound 2-(4-fluoro-phenyl)-3-(4-methyl-5,6, 7,8-tetrahydro-quinazolin-2-yl)-thiazolidin-4-one (4a) and 
compound 3-(4,6-dimethyl-pyrimidin-2-yl)-2-(2-methoxyphenyl)-thiazolidin-4-one (4e) were the most potent compounds of the series, exhibiting marked antibacterial activity against Pseudomonas fluorescens and Staphylococcus aureus.

\section{Conclusion}

In the present study, six new 4-thiazolidinone derivatives were synthesized, characterized, and evaluated for their antimicrobial potential. The compounds exhibited antimicrobial activity against the selected Gram-positive and Gram-negative bacterial strains and the fungal strains. Overall, 2-(4fluoro-phenyl)-3-(4-methyl-5,6,7,8-tetrahydro-quinazolin2-yl)-thiazolidin-4-one and 3-(4,6-dimethyl-pyrimidin-2yl)-2-(2-methoxy-phenyl)-thiazolidin-4-one were found to be the most potent members of the series. On the basis of the antimicrobial activity studies, it may be concluded that all the compounds have a broad spectrum of antimicrobial activity.

Thus, the study provides a lead for the syntheses and evaluation of more 4-thiazolidinone derivatives for antimicrobial activity, as the same could lead to the discovery of some promising agents.

\section{Conflict of Interests}

The authors declare that there is no conflict of interests regarding the publication of the paper.

\section{References}

[1] G. D. Wright and T. W. Daniel, "Chemotherapeutic agents," in Burger's Medicinal Chemistry and Drug Discovery, D. J. Abraham, Ed., p. 738, John Wiley \& Sons, Hoboken, NJ, USA, 2003.

[2] A. C. Tripathi, S. J. Gupta, G. N. Fatima, P. K. Sonar, A. Verma, and S. K. Saraf, "4-Thiazolidinones: the advances continue," European Journal of Medicinal Chemistry, vol. 72, pp. 52-77, 2014.

[3] K. Babaoglu, M. A. Page, V. C. Jones et al., "Novel inhibitors of an emerging target in Mycobacterium tuberculosis; substituted thiazolidinones as inhibitors of dTDP-rhamnose synthesis," Bioorganic and Medicinal Chemistry Letters, vol. 13, no. 19, pp. 3227-3230, 2003.

[4] F. L. Gouveia, R. M. B. de Oliveira, T. B. de Oliveira et al., "Synthesis, antimicrobial and cytotoxic activities of some 5arylidene-4-thioxo-thiazolidine-2-ones," European Journal of Medicinal Chemistry, vol. 44, no. 5, pp. 2038-2043, 2009.

[5] T. Esra, I. Küçükgüzel, E. D. Clercq, F. Sahin, and M. Güllüce, "Synthesis, characterization and screening of antimicrobial, antituberculosis, antiviral and anticancer activity of novel 1,3-thiazolidine-4-ones derived from 1-[2-(benzoylamino)-4(methylthio)butyryl]-4-alkyl/arylalkyl thiosemicarbazides," ARKIVOC Xiv, pp. 191-210, 2008.

[6] P. Vicini, A. Geronikaki, K. Anastasia, M. Incerti, and F. Zani, "Synthesis and antimicrobial activity of novel 2-thiazolylimino-5-arylidene-4-thiazolidinones," Bioorganic and Medicinal Chemistry, vol. 14, no. 11, pp. 3859-3864, 2006.
[7] S. Bondock, W. Khalifa, and A. A. Fadda, "Synthesis and antimicrobial evaluation of some new thiazole, thiazolidinone and thiazoline derivatives starting from 1-chloro-3,4dihydronaphthalene-2-carboxaldehyde," European Journal of Medicinal Chemistry, vol. 42, no. 7, pp. 948-954, 2007.

[8] C. J. Andres, J. J. Bronson, S. V. D’Andrea et al., “4-Thiazolidinones: novel inhibitors of the bacterial enzyme MurB," Bioorganic and Medicinal Chemistry Letters, vol. 10, no. 8, pp. 715-717, 2000.

[9] C. V. Kavitha, Basappa, S. N. Swamy et al., "Synthesis of new bioactive venlafaxine analogs: novel thiazolidin-4-ones as antimicrobials," Bioorganic \& Medicinal Chemistry, vol. 14, no. 7, pp. 2290-2299, 2006.

[10] A. Saeed, N. Abbas, and U. Flörke, "Synthesis and antibacterial activity of some novel 2-aroylimino-3-aryl-thiazolidin-4-ones," Journal of the Brazilian Chemical Society, vol. 18, no. 3, pp. 559$565,2007$.

[11] A. Dandia, R. Singh, S. Khaturia, C. Mérienne, G. Morgant, and A. Loupy, "Efficient microwave enhanced regioselective synthesis of a series of benzimidazolyl/triazolyl spiro [indolethiazolidinones] as potent antifungal agents and crystal structure of spiro[3H-indole-3,2' -thiazolidine]- $3^{\prime}$ (1,2,4-triazol-3yl)-2,4'(1H)-dione," Bioorganic and Medicinal Chemistry, vol. 14, no. 7, pp. 2409-2417, 2006.

[12] F. L. Gouveia, R. M. B. de Oliveira, T. B. de Oliveira et al., "Synthesis, antimicrobial and cytotoxic activities of some 5arylidene-4-thioxo-thiazolidine-2-ones," European Journal of Medicinal Chemistry, vol. 44, no. 5, pp. 2038-2043, 2009.

[13] H. H. Parekh, K. A. Parikh, and A. R. Parikh, "Synthesis of some 4-thiazolidinone derivatives as antitubercular agents," Journal of Sciences, Islamic Republic of Iran, vol. 15, no. 2, pp. 143-148, 2004.

[14] H. Altintaş, Ö. Ateş, S. Birteksöz, G. Ötük, M. Uzun, and D. Şatana, "Synthesis of Mannich bases of some 2,5-disubstituted 4-thiazolidinones and evaluation of their antimicrobial activities," Turkish Journal of Chemistry, vol. 29, no. 4, pp. 425-435, 2005.

[15] K. G. Desai, J. P. Raval, and K. R. Desai, "Neat reaction technology for the synthesis of 4-oxo-thiazolidines derived from 2-SH-benzothiazole and antimicrobial screening of some synthesized 4-thiazolidinones," Journal of the Iranian Chemical Society, vol. 3, no. 3, pp. 233-241, 2006.

[16] P. R. Kumar, M. S. Yadav, M. M. Kumar, and T. S. Rao, "Synthesis and antimicrobial activity of some new substituted aryloxy-4thiazolidinones," E-Journal of Chemistry, vol. 3, no. 1, pp. 44-48, 2006.

[17] T. J. Shah and V. A. Desai, "Synthesis of some novel fluorinated 4-thiazolidinones containing amide linkages and their antimicrobial screening," Arkivoc, vol. 2007, no. 14, pp. 218-228, 2007.

[18] T. M. de Aquino, A. P. Liesen, R. E. A. da Silva et al., "Synthesis, anti-Toxoplasma gondii and antimicrobial activities of benzaldehyde 4-phenyl-3-thiosemicarbazones and 2-[(phenylmethylene)hydrazono]-4-oxo-3-phenyl-5-thiazolidineacetic acids," Bioorganic and Medicinal Chemistry, vol. 16, no. 1, pp. 446-456, 2008.

[19] M. S. A. El-Gaby, G. A. M. El-Hag Ali, A. A. El-Maghraby, M. T. Abd El-Rahman, and M. H. M. Helal, "Synthesis, characterization and in vitro antimicrobial activity of novel 2-thioxo-4-thiazolidinones and 4,4' -bis(2-thioxo-4-thiazolidinone-3-yl)diphenylsulfones," European Journal of Medicinal Chemistry, vol. 44, no. 10, pp. 4148-4152, 2009. 
[20] J. R. Jackson, D. R. Patrick, M. M. Dar, and P. S. Huang, "Targeted anti-mitotic therapies: can we improve on tubulin agents?" Nature Reviews Cancer, vol. 7, no. 2, pp. 107-117, 2007.

[21] N. Jiang, X. Wang, Y. Yang, and W. Dai, "Advances in mitotic inhibitors for cancer treatment," Mini-Reviews in Medicinal Chemistry, vol. 6, no. 8, pp. 885-895, 2006.

[22] P. Kwan, G. J. Sills, and M. J. Brodie, "The mechanisms of action of commonly used antiepileptic drugs," Pharmacology and Therapeutics, vol. 90, no. 1, pp. 21-34, 2001.

[23] M. A. Rogawski, "Diverse mechanisms of antiepileptic drugs in the development pipeline," Epilepsy Research, vol. 69, no. 3, pp. 273-294, 2006.

[24] H. D. Troutman and L. M. Long, "The synthesis of 2, 3disubstituted-4-thiazolidonesl," Journal of the American Chemical Society, vol. 70, pp. 3436-3439, 1948.

[25] R. Kumar, T. K. Gupta, and S. S. Parmar, "Synthesis and anticonvulsant properties of some 4-thiazolidones," Journal für Praktische Chemie, vol. 312, no. 1, pp. 201-204, 1970.

[26] C. Dwivedi, T. K. Gupta, and S. S. Parmar, "Substituted thiazolidones as anticonvulsants," Journal of Medicinal Chemistry, vol. 15, no. 5, pp. 553-554, 1972.

[27] S. S. Parmar, C. Dwivedi, A. Chaudhari, and T. K. Gupta, "Substituted thiazolidones and their selective inhibition of nicotinamide-adenine dinucleotide dependent oxidations," Journal of Medicinal Chemistry, vol. 15, no. 1, pp. 99-101, 1972.

[28] A. Agarwal, S. Lata, K. K. Saxena, V. K. Srivastava, and A. Kumar, "Synthesis and anticonvulsant activity of some potential thiazolidinonyl 2-oxo/thiobarbituric acids," European Journal of Medicinal Chemistry, vol. 41, no. 10, pp. 1223-1229, 2006.

[29] Archana, V. K. Srivastava, and A. Kumar, "Synthesis of newer thiadiazolyl and thiazolidinonyl quinazolin-4(3H)-ones as potential anticonvulsant agents," European Journal of Medicinal Chemistry, vol. 37, no. 11, pp. 873-882, 2003.

[30] G. Capan, N. Ulusoy, N. Ergenc, A. Cevdet Ekinci, and A. Vidin, "Synthesis and anticonvulsant activity of new 3-[(2furyl) carbonyl] amino-4-thiazolidinone and 2-[(2-furyl) carbonyl] hydrazono-4-thiazoline derivatives," Farmaco, vol. 51, no. 11, pp. 729-732, 1996.

[31] S. A. H. El-Feky, "Synthesis and anticonvulsant properties of some novel quinazolinone thiazolidine and 4-thiazolidone derivatives," Die Pharmazie, vol. 48, no. 12, pp. 894-896, 1993.

[32] S. A. H. El-Feky and Z. K. Abd El-Samii, "Synthesis and anticonvulsant properties of some novel quinazolonethiosemicarbazone and 4-thiazolidone derivatives," Archiv der Pharmazie, vol. 324, no. 6, pp. 381-383, 1991.

[33] R. Ottaná, E. Mazzon, L. Dugo et al., "Modeling and biological evaluation of $3,3^{\prime}$-(1,2-ethanediyl)bis[2-(4-methoxyphenyl)thiazolidin-4-one], a new synthetic cyclooxygenase-2 inhibitor," European Journal of Pharmacology, vol. 448, no. 1, pp. 71-80, 2002.

[34] M. G. Vigorita, R. Ottanà, F. Monforte et al., "Chiral 3,3' -(1,2Ethanediyl)-bis[2-(3,4-dimethoxyphenyl)-4-thiazolidinones] with anti-inflammatory activity. Part 11: evaluation of COX-2 selectivity and modelling," Bioorganic and Medicinal Chemistry, vol. 11, no. 6, pp. 999-1006, 2003.

[35] M. G. Vigorita, T. Previtera, R. Ottana et al., “3,3'-Bi(1,3thiazolidin-4-one) system. VIII. 3,3'-(1,2-Ethanediyl) derivatives and corresponding $1,1^{\prime}$-disulfones: synthesis, stereochemistry and antiinflammatory activity," Farmaco, vol. 52, no. 1, pp. 43-48, 1997.
[36] A. Kumar, C. S. Rajput, and S. K. Bhati, "Synthesis of 3-[4'(p-chlorophenyl)-thiazol-2'-yl]-2-[(substituted azetidinone/ thiazolidinone)-aminomethyl]-6-bromoquinazolin-4-ones as anti-inflammatory agent," Bioorganic and Medicinal Chemistry, vol. 15, no. 8, pp. 3089-3096, 2007.

[37] S. K. Bhati and A. Kumar, "Synthesis of new substituted azetidinoyl and thiazolidinoyl-1,3,4-thiadiazino (6,5-b) indoles as promising anti-inflammatory agents," European Journal of Medicinal Chemistry, vol. 43, no. 11, pp. 2323-2330, 2008.

[38] R. Pink, A. Hudson, M.-A. Mouriès, and M. Bendig, "Opportunities and challenges in antiparasitic drug discovery," Nature Reviews Drug Discovery, vol. 4, no. 9, pp. 727-740, 2005.

[39] J. Pepin, F. Milord, C. Guern, B. Mpia, L. Ethier, and D. Mansinsa, "Trial of prednisolone for prevention of melarsoprolinduced encephalopathy in gambiense sleeping sickness," The Lancet, vol. 333, no. 8649, pp. 1246-1250, 1989.

[40] M. A. J. Ferguson and G. A. M. Cross, "Myristylation of the membrane form of a Trypanosoma brucei variant surface glycoprotein," Journal of Biological Chemistry, vol. 259, no. 5, pp. 3011-3015, 1984.

[41] M. A. J. Ferguson, J. S. Brimacombe, J. R. Brown et al., "The GPI biosynthetic pathway as a therapeutic target for African sleeping sickness," Biochimica et Biophysica Acta-Molecular Basis of Disease, vol. 1455, no. 2-3, pp. 327-340, 1999.

[42] T. K. Smith, B. L. Young, H. Denton, D. L. Hughes, and G. K. Wagner, "First small molecular inhibitors of T. brucei dolicholphosphate mannose synthase (DPMS), a validated drug target in African sleeping sickness," Bioorganic and Medicinal Chemistry Letters, vol. 19, no. 6, pp. 1749-1752, 2009.

[43] E. E. Carlson, J. F. May, and L. L. Kiessling, "Chemical probes of UDP-galactopyranose mutase," Chemistry and Biology, vol. 13, no. 8, pp. 825-837, 2006.

[44] R. K. Rawal, Y. S. Prabhakar, S. B. Katti, and E. De Clercq, "2(Aryl)-3-furan-2-ylmethyl-thiazolidin-4-ones as selective HIVRT inhibitors," Bioorganic and Medicinal Chemistry, vol. 13, no. 24, pp. 6771-6776, 2005.

[45] Y. S. Prabhakar, R. K. Rawal, M. K. Gupta, V. R. Solomon, and S. B. Katti, "Topological descriptors in modeling the HIV inhibitory activity of 2-aryl-3-pyridyl-thiazolidin-4-ones," Combinatorial Chemistry and High Throughput Screening, vol. 8, no. 5, pp. 431-437, 2005.

[46] R. K. Rawal, R. Tripathi, S. B. Katti, C. Pannecouque, and E. De Clercq, "Design, synthesis, and evaluation of 2-aryl-3heteroaryl-1,3-thiazolidin-4-ones as anti-HIV agents," Bioorganic \& Medicinal Chemistry, vol. 15, no. 4, pp. 1725-1731, 2007.

[47] J. Balzarini, B. Orzeszko, J. K. Maurin, and A. Orzeszko, "Synthesis and anti-HIV studies of 2-adamantyl-substituted thiazolidin-4-ones," European Journal of Medicinal Chemistry, vol. 42, no. 7, pp. 993-1003, 2007.

[48] J. Balzarini, B. Orzeszko-Krzesińska, J. K. Maurin, and A. Orzeszko, "Synthesis and anti-HIV studies of 2-and 3adamantyl-substituted thiazolidin-4-ones," European Journal of Medicinal Chemistry, vol. 44, no. 1, pp. 303-311, 2009.

[49] R. K. Rawal, R. Tripathi, S. B. Katti, C. Pannecouque, and E. De Clercq, "Synthesis and evaluation of 2-(2,6-dihalophenyl)3-pyrimidinyl-1,3-thiazolidin-4-one analogues as anti-HIV-1 agents," Bioorganic and Medicinal Chemistry, vol. 15, no. 9, pp. 3134-3142, 2007.

[50] S. M. Fitzgerald, B. K. Kemp-Harper, H. C. Parkington, G. A. Head, and R. G. Evans, "Endothelial dysfunction and arterial pressure regulation during early diabetes in mice: roles for 
nitric oxide and endothelium-derived hyperpolarizing factor," The American Journal of Physiology-Regulatory Integrative and Comparative Physiology, vol. 293, no. 2, pp. R707-R713, 2007.

[51] V. Calderone, S. Rapposelli, A. Martelli et al., "NO-glibenclamide derivatives: prototypes of a new class of nitric oxidereleasing anti-diabetic drugs," Bioorganic and Medicinal Chemistry, vol. 17, no. 15, pp. 5426-5432, 2009.

[52] P. Alexiou, K. Pegklidou, M. Chatzopoulou, I. Nicolaou, and V. J. Demopoulos, "Aldose reductase enzyme and its implication to major health problems of the 21st century," Current Medicinal Chemistry, vol. 16, no. 6, pp. 734-752, 2009.

[53] V. Brizzi, M. Francioli, M. Brufani, L. Filocamo, G. Bruni, and P. Massarelli, "Synthesis, binding affinity and selectivity of new $\beta_{1}$ - and $\beta_{2}$-adrenoceptor blockers," Farmaco, vol. 54, no. 11-12, pp. 713-720, 1999.

[54] R. J. Bing, T. Yamamoto, H. Kim, and R. H. Grubbs, "The pharmacology of a new nitric oxide donor: B-NOD," Biochemical and Biophysical Research Communications, vol. 275, no. 2, pp. 350-353, 2000.

[55] S. V. Bhandari, K. G. Bothara, A. A. Patil et al., "Design, synthesis and pharmacological screening of novel antihypertensive agents using hybrid approach," Bioorganic and Medicinal Chemistry, vol. 17, no. 1, pp. 390-400, 2009.

[56] S. M. Grundy, "Drug therapy of the metabolic syndrome: minimizing the emerging crisis in polypharmacy," Nature Reviews Drug Discovery, vol. 5, no. 4, pp. 295-309, 2006.

[57] N. K. Jacob and G. N. Kutty, "Synthesis and hypolipidemic activity of a thiazolidinone derivative," Indian Drugs, vol. 41, no. 2, pp. 76-79, 2004.

[58] G. K. Nampurath, S. P. Mathew, V. Khanna, R. T. Zachariah, S. Kanji, and M. R. Chamallamudi, "Assessment of hypolipidaemic activity of three thiazolidin-4-ones in mice given high-fat diet and fructose," Chemico-Biological Interactions, vol. 171, no. 3, pp. 363-368, 2008.

[59] F. Chimenti, A. Bolasco, D. Secci et al., "Investigations on the 2thiazolylhydrazyne scaffold: synthesis and molecular modeling of selective human monoamine oxidase inhibitors," Bioorganic and Medicinal Chemistry, vol. 18, no. 15, pp. 5715-5723, 2010.

[60] T. Srivastava, S. B. Katti, and W. Haq, "Carbodiimide mediated synthesis of 4-thiazolidinones by one-pot three-component condensation," Tetrahedron, vol. 58, no. 38, pp. 7619-7624, 2002.

[61] V. Gautam, V. Chawla, P. K. Sonar, and S. K. Saraf, "Syntheses, characterization and antimicrobial evaluation of some 1, 3, 5trisubustituted pyrazole derivatives," E-Journal of Chemistry, vol. 7, no. 4, pp. 1190-1195, 2010.

[62] M. Agrawal, P. K. Sonar, and S. K. Saraf, "Synthesis of 1,3,5-trisubstituted pyrazoline nucleus containing compounds and screening for antimicrobial activity," Medicinal Chemistry Research, vol. 21, no. 11, pp. 3376-3381, 2012.

[63] O. P. Agrawal, P. K. Sonar, and S. K. Saraf, "4-Thiazolidinone and 1-thia-3,4,9-triaza fluorene conjugates: synthesis, characterization and antimicrobial screening," Medicinal Chemistry Research, vol. 22, no. 4, pp. 1972-1978, 2013. 

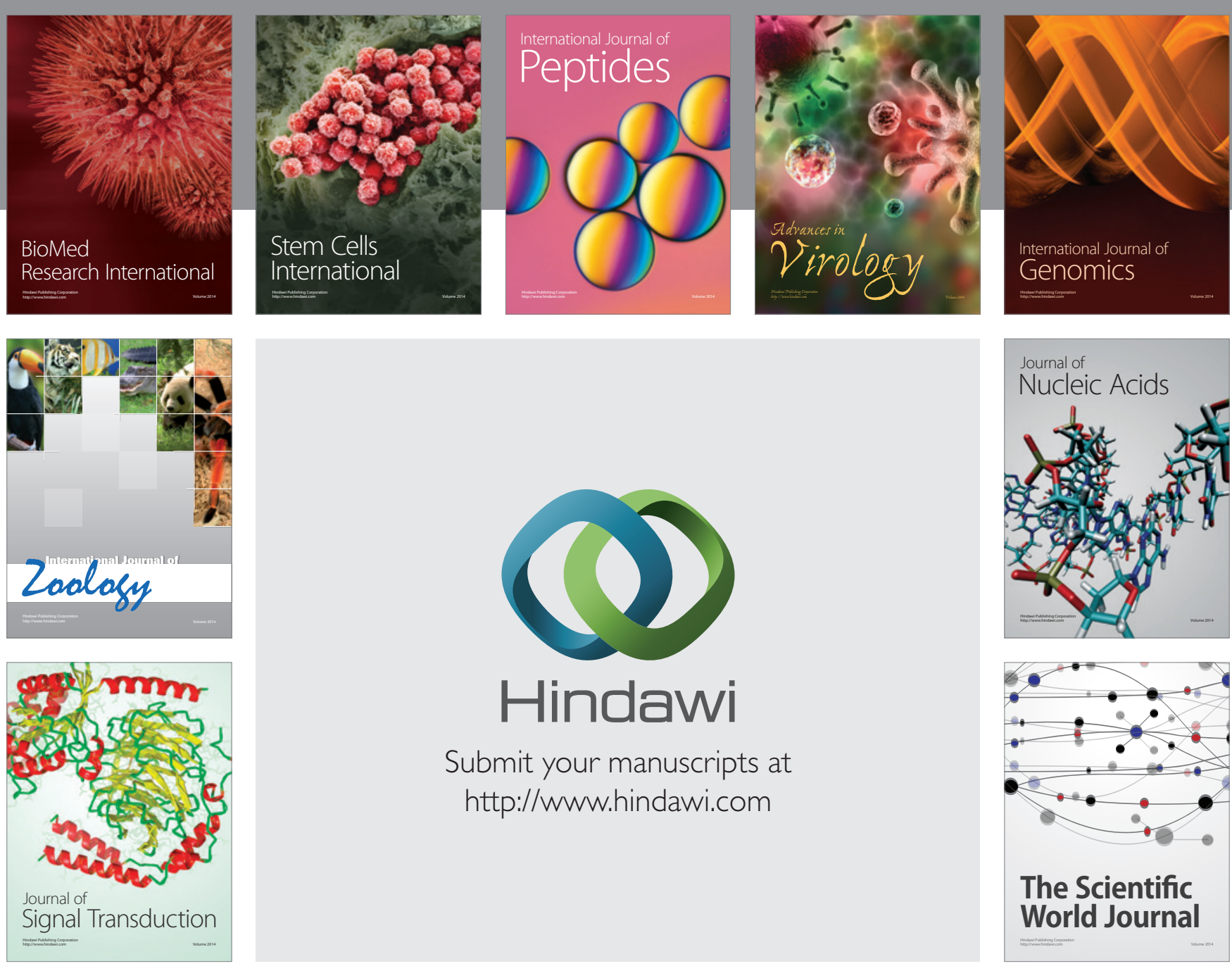

Submit your manuscripts at

http://www.hindawi.com
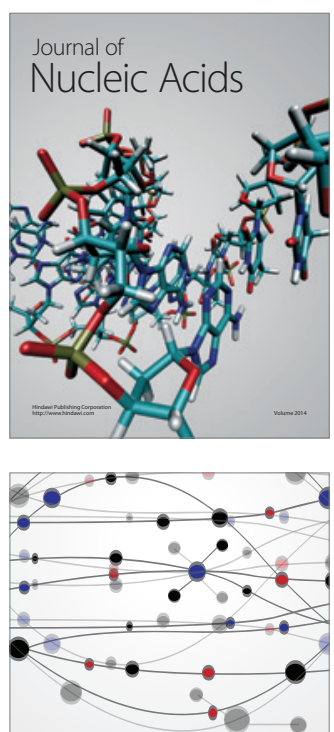

The Scientific World Journal
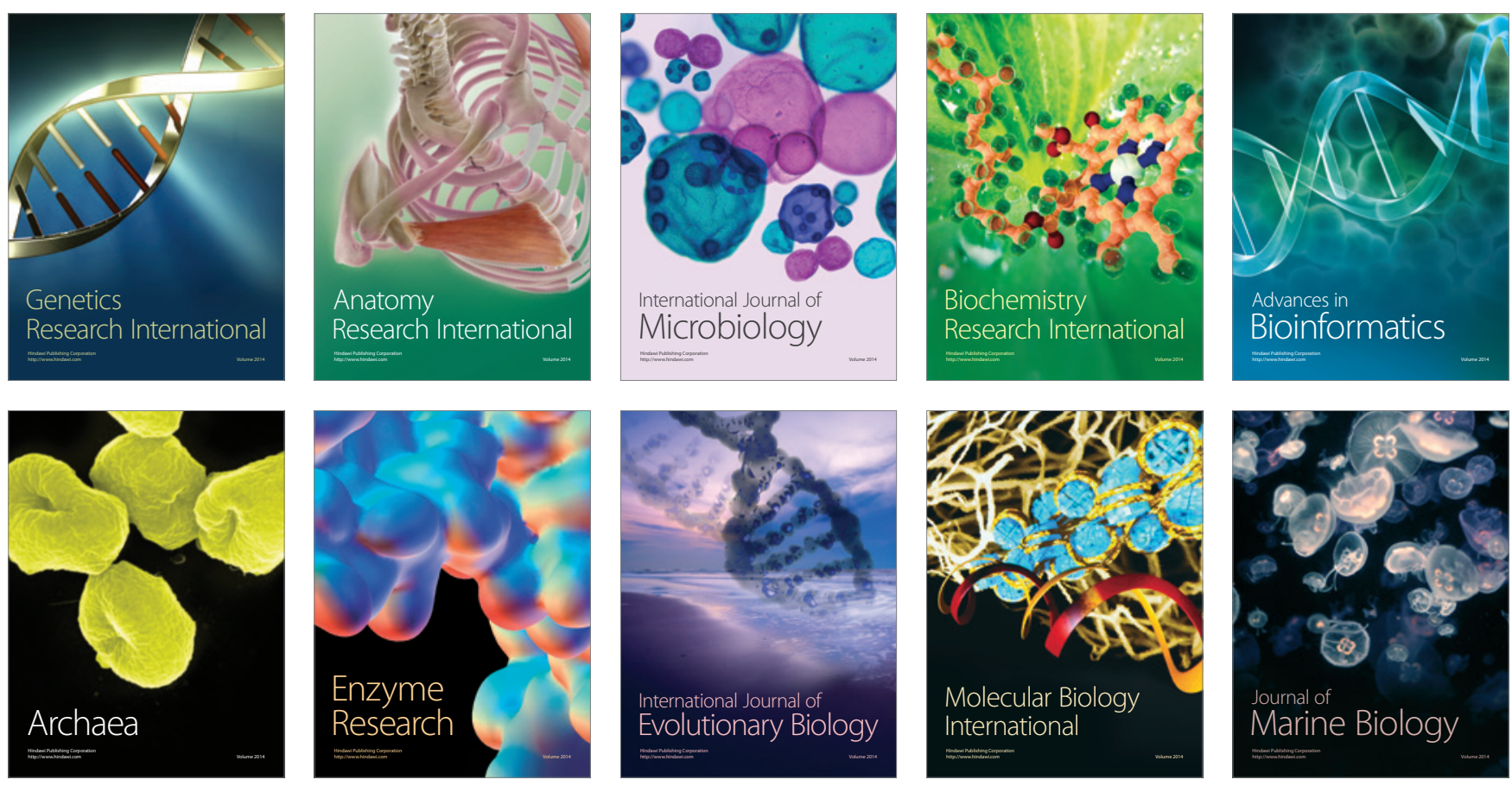